\title{
Facilitating factors for the job placement of workers with intellectual disabilities: supervisors and coworker mentors perspectives
}

Miquel Àngel Pellicena, Ignasi Ivern, Climent Giné and Olga Múries

\begin{abstract}
Purpose - This study aims to contribute to a better understanding of organizational strategies, attitudes and supports that can help people with intellectual disabilities to access competitive jobs through supported employment.
\end{abstract}

Design/methodology/approach - A multiple case study was carried out based on an intentional sampling involving the coworker mentors of six people with intellectual disabilities currently working in standardized environments. Semi-structured interviews were performed with the participants, and an inductive thematic analysis was used for data analysis.

Findings - The study identified five critical factors in the work of people with intellectual disabilities in standardized work environments, which potentially could act as facilitators or as obstacles, depending on how they were managed. The study also identified two key factors that acted mainly as facilitators and one as an obstacle.

Originality/value - The study reveals the existence of factors that sometimes act as facilitators and sometimes as obstacles, depending on how they are managed by the company leaders or the disabled worker himself.

Keywords Case study, Intellectual disability, Quality of life, Supported employment, Job placement, Coworker mentor

Paper type Research paper

Introduction

The need to align the supports and services offered to people with intellectual and developmental disabilities (IDD) throughout the life span with their wishes, interests and quality of life has been highlighted by various authors in recent years (Buntix and Schalock, 2010; Schalock et al., 2008; Thompson et al., 2009).

In Spain, the achievement of this alignment is a constant struggle in all stages of life, particularly as far as adulthood is concerned. Less than $9 \%$ of adults with IDD have access to paid work in the community alongside colleagues without this condition; the vast majority remains in sheltered, segregated, underpaid employment facilities with limited opportunities for self-determination and community participation (Jordán de Urríes and Verdugo, 2012).

The purpose of this study is to contribute to a better understanding of organizational strategies, attitudes and supports that can help people with IDD access competitive jobs through supported employment (SE) in Spain. Even though in our country several research regarding SE have been carried out, most have focused on the structural aspects (number
Miquel Àngel Pellicena, Ignasi Ivern, Climent Giné and Olga Múries are all based at the Faculty of Psychology, Education and Sport Sciences,

Blanquerna, Universitat Ramon Llull, Barcelona, Spain.
Received 20 November 2019 Revised 21 March 2020 5 June 2020

Accepted 8 August 2020

(c) Miquel Àngel Pellicena, Ignasi Ivern, Climent Giné and Olga Múries. Published by Emerald Publishing Limited. This article is published under the Creative Commons Attribution (CC BY 4.0) licence. Anyone may reproduce, distribute, translate and create derivative works of this article (for both commercial and non-commercial purposes), subject to full attribution to the original publication and authors. The full terms of this licence may be seen at http:// creativecommons.org/licences/ by/4.0/legalcode 
of workers, daily worked hours, wages, etc.) as well as on the impact of SE on the perceived quality of life of the workers (Jordán de Urríes et al., 2006; Jordán de Urríes et al., 2012; Santamaría et al., 2012; Verdugo et al., 2006; Verdugo et al., 2009). Thus, it is deemed necessary to gain greater understanding of factors related to management and working culture that facilitate role success. Our aim is to help companies and colleagues to value people with IDD more and to overcome the fears and prejudices that entail a barrier to their hiring.

SE emerged in the 1970s and 1980s in the USA as a consequence of normalization policies (Nirje, 1980; Wolfensberger, 1972) and the recognition of the rights of people with disabilities, particularly those with IDD, to promote competitive employment. According to Wehman (2012), SE means competitive employment in integrated community settings for individuals with severe disabilities with ongoing supports services to maintain a job.

For years, in many countries there has been, and still exists, a wide political, economic and technical debate about whether the best option for the work of people with IDD is SE or sheltered employment that has been the most accepted practice for many decades (Wehman, 2012). There are two key arguments in favor of SE. First is a values-based rationale. The progressive recognition of the rights of people with IDD, in particular full participation in the community and the increasing appreciation of these people based on their strengths and capacities, advocate the willingness and appropriateness of people with IDD access a job within the community. Moreover, Wehman (2012) summarize the benefits of SE in the past 25 years both for workers and for employers. People with IDD find meaning in their lives, earn money that allows them to make decisions and direct their lives, make relationships, gain new knowledge, train cognitive skills and contribute to creating values in companies such as acceptance of difference, tolerance and support.

Second, there is also an economic rationale. The employer gets a good employee and receives economic support for job acquisition and retention (Mank et al., 2003; Revell et al., 1999; Wehman et al., 2014). In addition, Almalky (2020) states that SE of individuals with IDD has a positive influence on their self-esteem, self-confidence, career progression and independence level; furthermore, the work of such individuals provides a source of income and enables them to contribute to the national economy through taxes.

It is true that people with IDD are exposed to certain risks associated with their vulnerability, such as bullying or the possibility of their partners ignoring or rejecting them. However, these situations also occur in companies in relation to other colleagues, so knowing how to deal with these situations is part of the agenda of any manager.

SE in Spain, and more specifically in Catalonia, where the research has been carried out, has had a poor development. Jordán de Urríes and Verdugo (2012) stated that, even though Spain was one of the first European countries that started SE, its development was not prioritized when compared to other forms of sheltered work. In 2010, there were 207 SE agencies in Spain that employed 5,539 people with IDD, whereas, in the same year, there were 1,871 sheltered work centers that served 59,185 people with IDD (Jordán de Urríes and Verdugo, 2012). Therefore, only 9.96\% of the work centers corresponded to SE. In Catalonia, where SE's first initiative was carried out by Aura Foundation in 1989, the situation does not differ and it is well below the SE rates in USA where integrated employment accommodates $26 \%$ of people with IDD while sheltered employment serves 50\% (Almalky, 2020).

The main reason for this disproportion in Spain has to do with the government's priorities, which take the form of social policies and funding that are clearly in favor of sheltered work centers. Consequently, the agencies that promote the SE in Spain are in a situation of weakness and insecurity that makes it very complex to fulfill their obligations. Despite that, they continue working to ensure that their commitment to competitive work and the 
recognition of the right of people with IDD to an improved quality of life gradually penetrates the government and society (Departament de Treball, 2009).

Another reason that hinders the SE progress in Spain refers to social prejudices, and particularly of managers and supervisors, toward people with IDD. The prevailing medical model that leads to paying attention fundamentally to the deficit, to what they cannot do, to possible communication and relationship problems, in short, to the devaluation of the person, acts as a brake on their possibility to be hired by employers.

Lack of knowledge about the capacities of people with IDD and social prejudices are shown as important barriers to hiring people with IDD. The Observatorio Estatal de la Discapacidad (2017) states that there are few employment opportunities for people with IDD because of ignorance or dis-interest. In this sense, Down España (2016, p. 34) points out that:

In general, there is a great lack of knowledge among businessmen about what are the professional competencies and the potential in terms of job performance of people with intellectual disabilities. This lack of knowledge has traditionally been fueled by ideas or stereotypes that relegated people with Down syndrome or intellectual disability to performing non-productive tasks.

Moreover, there is a lack of knowledge - and, to a certain extent, fear - about the organizational measures and strategies required for the success of possible hiring, thinking about the company's management and coworkers as well as the benefits (Down España, 2016). Indeed, since the 80 s of the past century, the government forced companies to hire people with disabilities in exchange of some tax benefits. While it can be said that this situation has meant significant progress for people with disabilities, the greatest beneficiaries were people with physical or sensory disabilities, without having a great impact in the field of IDD (Instituto Nacional de Estadística, 2008).

Therefore, the current study contributes to understanding organizational strategies, attitudes and supports that help people with IDD access to competitive employment in the community and its maintenance so that it can be useful to companies and support staff of agencies that promote SE.

\section{Research aim}

The objective of this study was to get to know which organizational and attitudinal factors were perceived by coworker mentors and supervisors as facilitators and which as obstacles to enter the labor market and to maintain the job in people with IDD. The study wanted to focus in companies that have in their workforce people with IDD in competitive employment through SE.

\section{Method}

We conducted a qualitative study in the framework of the constructivist and critical paradigms. On the one hand, we understand reality as a subjective construction in which the interpretations and attributions of meaning carried out by subjects are fundamental. On the other hand, we identify ourselves with research committed to social reality, which seeks to transform the social conditions and structures that discriminate and exclude certain people, correcting inequalities and favoring the development and well-being (quality of life) of society as a whole.

We used the case study method, in its multiple case study modality (Yin, 2018), which involved conducting and analyzing interviews with various actors involved in the process to identify common themes and elements of differentiation among participants. Case study 
research represents a good strategy to obtain an in-depth knowledge of a unique entity and limited in a real-life context (Abma and Stake, 2014).

The study was approved by the Ethics and Research Committee of the Blanquerna Faculty of Psychology, Educational and Sports Sciences at Ramon Llull University.

\section{Participants}

Following Anguera et al. (1995), we carried out an intentional sampling according to two criteria. First, IDD workers met certain conditions:

- that they had followed a training process in Aura Foundation;

- that they had achieved a successful labor access in different companies; and

- that they maintained their employment after the first year of the hiring date.

Second, the coworker mentors expressed their agreement to collaborate in the access process ran by Aura Foundation. In summary, six cases of people with IDD belonging to Aura Foundation and their corresponding coworkers and supervisors were selected for the study.

Aura Foundation is the first agency to provide SE services to people with IDD in Spain (Verdugo et al., 1998). It is located in Barcelona and after 30 years of experience, continues to have a high esteem in the field of SE. In 2018, Aura Foundation served 240 people (52\% women and $48 \%$ men) in its different services and got 40 new contracts, reaching 171 people with a contract in competitive employment. Some of the different services that Aura Foundation offers are:

- initial training program aimed at teenagers and young people, prior to job training;

- labor insertion program consisting of training in independent and social skills and between two and four months training practices in the workplace with the support of a job coach;

- continuing training programs;

- independent life training program in a flat shared with university students and coordinated by the staff of Aura Foundation;

- the Club, where people participate in leisure time and community activities; and

- the neuropsychology service aimed at cognitive stimulation and biofeedback (Aura Foundation, 2019).

In recognition of their work, it is worth noting that Aura Foundation was invited as a speaker at the World Down Syndrome Day Conference held at the United Nations in New York on March 21, 2018.

Eight coworker mentors from six IDD workers participated in the interviews; four of them were colleagues and four supervisors. In two cases, two coworker mentors were interviewed. The same researcher conducted all interviews. Tables 1 and 2 show the demographic data and the employment status of the coworker mentors as well as those of the workers with IDD. Codes have been used to identify participants rather than names to guarantee confidentiality.

\section{Data collection}

The main instrument of data collection was the semi-structured interview. The interviews were conducted in the companies between October 2017 and February 2018 and recorded in audio for later transcription and analysis. However, one of the researchers had already 
Table 1 Demographic data and employment situation of coworker mentors

Coworker mentor Sex Job

Position Worker

\begin{tabular}{lllll}
\hline C0 & F & University staff & Administrative officer & T0 \\
C1 & F & Health center & Purchasing manager & T1 \\
C2 & M & University staff & Facilities manager & T2 \\
C3c & F & Research center & Management assistant & T3 \\
C3n & F & Research center & Coordinator & T3 \\
C4 & F & Clothing store & Store manager & T4 \\
C5m & F & Professional association & Human resources director & T5 \\
C5v & F & Professional association & Human resources technician & T5
\end{tabular}

\section{Table 2 Demographic data and employment situation of workers with IDD}

\begin{tabular}{llllll} 
Worker & Age & Sex & IDD etiology & Seniority & Position \\
\hline T0 & 36 & M & Down S. & 16 & Service assistant \\
T1 & 26 & F & Unknown etiology & 3 & Laboratory assistant \\
T2 & 44 & M & Down S. & 25 & Cleaning assistant \\
T3 & 32 & F & Down S. & 13 & Administrative assistant \\
T4 & 25 & F & Unknown etiology & 3 & Warehouse assistant \\
T5 & 29 & M & Down S. & 2 & Administrative assistant
\end{tabular}

conducted a first pilot interview in 2016 that served to adjust the order and content of some thematic blocks. The written consent was requested from those personal legal representatives for IDD's people and from coworker mentors both to participate in the research and to record the conversation.

Based on the available literature (Alomar, 2004; Kvale, 2011; Pallisera et al., 2005), the thematic blocks that shaped the script of the interviews were identified, as shown in Table 3.

In addition, Table 4 shows the definition of the different roles involved in the research.

\section{Data analysis}

For data analysis, we adopted the thematic analysis proposal of Braun and Clarke (2006) that includes the following six steps:

1. familiarizing with the data;

2. generating initial codes;

3. searching for themes;

Table 3 Thematic blocks of interviews to coworkers mentors about the worker

\begin{tabular}{ll} 
Block & Themes \\
\hline 1 & Welcome, demographic data of the attendees and aim of the interview \\
2 & Questions about the first days in the company \\
3 & Questions about the content and conditions of the work \\
4 & Questions about his/her communication and social skills \\
5 & Questions about the role of the job coach \\
6 & Questions about the role of the co-working mentor and other colleagues \\
7 & Questions about the factors that help the worker to enter and maintain the workplace \\
8 & Questions about hinder factors \\
9 & Ending questions
\end{tabular}




\section{Table 4 Definition of roles}

Role

Definition

Job coach

Means the professional who works in a SE services provider and gives all the supports necessary to the employer and the worker with IDD until getting his/her autonomy in the workplace

Coworker Means the person, often a colleague, who provides support, training or companionship to the worker with IDD to perform mentor their obligations in the workplace and participate in the life of the company. He frequently works in collaboration with the job coach

Supervisor Means the immediate head of the worker with IDD in the workplace
4. reviewing themes;

5. defining and naming themes; and

6. writing the results.

In the first step, the researcher and a research assistant proceeded to transcribe and review the data obtained in the interviews. As some authors pointed out, the fact of transcribing already represents a first approximation to the data and makes it possible to begin to become familiar with them (Riessman, 1993). For transcription, we have adopted the conventions proposed by Poland (2002) with a few small variations to make the text more comprehensive. In the following steps (2 and 3), some initial codes were generated separately by two of the authors and an external researcher from the ideas that emerged in the interviews. These codes were subsequently derived into themes that seemed relevant for the research purposes. The codes and themes obtained separately were subjected to interrater agreement test between the three researchers. Starting from an initial coincidence of $78.94 \%$, and after a process of discussion and analysis, full agreement on the themes was reached. Subsequently (steps 4 and 5), the themes were reviewed to verify that they made sense for themselves and that they did not overlap. Finally, the results were drafted (step 6).

\section{Results}

Our research allowed us to identify five critical factors in the work of people with IDD, which potentially could act as facilitators or as an obstacle, depending on how they were managed. Besides, we identified two key factors that acted mainly as facilitators and one as an obstacle (Table 5).

\section{Key factors that potentially acted as facilitators or as an obstacle}

Task planning and scheduling. It refers to how to organize the tasks assigned to the workers, their clarity, routines and calendars; the criteria considered when the tasks should be assigned and if they fit the IDD's interests and abilities.

Table 5 Results: categories and factors

\begin{tabular}{ll} 
Categories & Factors \\
\hline Key factors that potentially acted as & Task planning and scheduling \\
facilitators or as an obstacle & Monitoring and follow-up \\
& Quality of the relationship and communication with the \\
& supervisor and colleagues \\
& Attitude and capacity of the worker with IDD \\
& Understanding disability \\
Key factors acting as facilitators & Corporate social responsibility \\
& Presence and accompaniment of the job coach \\
Key factors that act as an obstacle & Lack of a period of adaptation
\end{tabular}


All of the people interviewed stated that one of the main factors that facilitated the success of the work of colleagues with IDD is that the tasks they must perform should be identified and scheduled so that they have a clear idea of what they should do and when. Thus, for example, C2 explained the following: "We gave him a to-do list with schedule and, well, that is his job. [...] He knows what to do. He has his schedule in his locker room, where he reads what he has to do that day." In this sense, the majority of people interviewed said that if the person with IDD received a list of tasks and a calendar, everything was more straightforward. As obstacles, respondents mentioned the lack of organization in the tasks' assignment as one of the difficulties they had to face.

In most of the interviews carried out, respondents highlighted the need to adjust tasks to the worker's interests and abilities. Thus, for example, C3n said about her colleague with IDD: "If you ask her to do a different work, she is super motivated because she changes the tasks." C2, for his part, commented: "In the beginning, [...] he got tired of always doing the same thing $[\ldots]$ and wanted to do more things than he did."

Monitoring and follow-up. It refers to the actions carried out, usually by the coworker mentor and by the supervisor, to check that the task was done correctly and that workers were comfortable with their work. It includes the correction of mistakes that workers might make, as well as the recognition of their achievements.

Some participants emphasized the importance of keeping track of the tasks the IDD's workers did so that they know whether or not the tasks were performed correctly or if they needed to correct something in the way the IDD person executed the task. The participant $\mathrm{C} 5 \mathrm{~m}$ pointed out the figure of the coworker mentor as the most suitable person to carry out this follow-up. In monitoring, the demand for a job well done, and compliance with obligations and standards should be present. An example of this can be found in the words of $\mathrm{C} 4$ :

She is a very affectionate girl; she immediately volunteers (helped). Yes, we indeed had to slow down the subject of "affection" a little, because if you let her speak, does not work and, well we had to set some guidelines for her.

The follow-up should not only have as a consequence the correction of mistakes, but also the recognition of a well-done job. Support, help and adaptation to the needs of the worker with IDD for their appropriate work, more intensely at the beginning and leaving more autonomy as the worker acquires more skills in their tasks, should also be present. Another participant, in this case C5v, referred to the fact that the follow-up should also be focused on more personal aspects, such as "knowing how to detect if something is happening to him or not, if he is well, if he likes the tasks he does [...] to give him confidence and to make him feel at ease."

On the other hand, some participants, such as $\mathrm{C} 5 \mathrm{~m}$, also pointed out the difficulties because of the lack of adequate follow-up when the worker had moved to a place far from his or her coworker mentor or when the coworker mentor was not present because of temporary sick leave, as is the case of CO: "Sometimes, he has to go to deliver the mail, isn't it? And he is lost; he is lost. . .He is not lost, but it takes longer than normal."

Quality of the relationship and communication with the supervisor and colleagues. It refers to the type of treatment that the colleagues and supervisors give to the IDD worker and the communication fluidity between them.

This issue was one of the most highlighted in the interviews. All the people interviewed pointed out that treating the person with IDD as one more, adapting to their needs, without discriminating against them because of their disability, but at the same time helping them to grow as a person and as a professional within the team was a fundamental factor for a correct access and maintaining the workplace. This treatment referred both to work situations as well as more informal situations that always arose in moments of rest or outside 
the work environment. C1 used to say: "Just as she helps me and I help her, I help her just as I help another colleague so that everything is a chain and we get along." Thus, the moments of breakfast in the cafeteria were also highlighted by some participants as situations that helped labor insertion, as C0 explained about his colleague with IDD: "When breakfast time arrives [...] he picks up all his colleagues [...] mainly the closest and if one is not found, he calls him on the internal telephone."

At times, dealing with other workers represented a source of difficulty, especially if the IDD person claimed attention that, for the rest of the co-workers, was considered excessive. C4 put it this way:

When she does her job, she likes to show it to you. [...] Then you go, you say "Oh, very good, very good!" [...] But maybe, with her colleagues, she tells them three or four times and[...] (and they don't pay so much attention to her).

On the other hand, this factor also seemed to act as an obstacle in some cases, mainly because of lack of fluency in communication, shyness or because of the worker's difficulties in expressing doubts or asking questions, especially with people he does not know. C5v said the following:

He finds it difficult to ask. When we had a problem, it was because of that, because he has made his own decision and [...] No, no! Ask questions, then nothing happens.

Of the eight individuals who participated in the investigation, four were the worker's supervisor. From the perspective of these participants, a relationship that facilitates keeping the workplace should be based on the same treatment that would be given to any other colleague.

On the other hand, this issue also could act as an obstacle in some cases, either because the worker was blocked by the tone with which he was spoken when he was wrong, or because he considered that he was not paid attention or because he hid information from his supervisor to not be reprimanded. This is the case that C3c explained: "Sometimes she confuses us by saying things that are not true and does not recognize it until a few hours or until the next day."

Attitude and capacity of the worker with intellectual and developmental disabilities in the fulfillment of his obligations as well as the emotional instability for extra-laboral reasons. This topic refers to predisposition and abilities that the worker shows toward his tasks and before the demands of other colleagues. They have their origin in the worker himself (attitudes and abilities) and affect both the fulfillment of the job and the communication with the supervisor and colleagues.

All the participants interviewed referred to the attitude of the worker with IDD as a key element in the success of their work. The desire to work, to feel useful, to learn, combined with a sense of responsibility or even perfectionism and a predisposition to help colleagues, were the most highlighted attitudes. As an example, we would like to highlight the words of C0: "I think that for him, coming to work is very important, very important, and he is a worker, very hard worker, very good colleague and very responsible."

On the other hand, some respondents stated that on certain occasions, difficulties did arise because of lack of interest, lack of perseverance, loss of attention or failure to develop some necessary skills such as reading or writing. Likewise, the emotional stability of the worker with IDD was sometimes altered by problems outside the workplace, such as the worker's health problems, the illness or even the death of a close relative.

Understanding disability. It refers to the knowledge (or lack of knowledge) that the colleagues and supervisors of the worker with IDD have about disability and to the ideas, fears, beliefs, feelings and expectations that arise from it. 
Some participants stated that, in the beginning, the lack of knowledge about disability generated doubts and fears in them when they did not know how to treat their peers with IDD, nor if the IDD colleague could carry out his work in a satisfactory way. On the other hand, some answers also highlighted a particular conception of disability as a wrong move of fate and the need to protect people who suffer from it by offering them a place where they feel happy.

Many of the people interviewed, however, stated that working with a person with IDD allowed them to discover that IDD people could contribute to the team and modified their misconceptions about disability. For example, C3n said:

I really did not have any such experience when I met her, [...] working with a person with a disability, and I was surprised at what she is capable [...], and I think everyone here is surprised because she is competent.

\section{Key factors acting as facilitators}

Corporate social responsibility (willingness to hire) and introducing the worker to colleagues. On this issue, we place the circumstances that revolve around the decision to incorporate a worker with IDD into the company's workforce. We included the motivations that led to this decision together with the way the company communicates this decision to the rest of the staff and introduces him to their new colleagues.

The decision to hire a worker with IDD is one of the issues that some participants pointed out as an essential factor for successful entering the labor force, especially in those companies where hiring was not mandatory. This is the case of $\mathrm{C} 1$, who in the interview said the following:

I would highlight the company, because [...] we live in a society that does not yet have the concept of having people with intellectual disabilities working [...] and it was the doctor (director) who came to Aura Foundation without being obliged to do so.

In this same line, C3n emphasized the will of the first director of the center: "I think it was very nice the fact that, well, the founder and first director of the center considered that it was an opportunity for a person with a disability and did it." The company's sense of social responsibility seemed to be the reason behind these quotes.

Some participants had mentioned the importance of future colleagues of the disabled worker being informed in advance of the incorporation of a person with IDD into the team. They also desired to receive this information preferably by a person with responsibility inside the company and who also knows how to convey a positive perspective of such incorporation.

Presence and accompaniment of the job coach. It refers to actions of the job coach that contributed to a successful process from the perspective of the coworker mentor.

The majority of research participants perceive the figure of the job coach as a critical factor for entering and maintaining the workplace of a person with IDD. Their advice is considered very important to guide the actions of the worker with IDD, his colleagues and supervisors. This was confirmed by $\mathrm{C} 2$, when asked where was the secret of an appropriate entering and maintaining the workplace: "I would say that the secret is the job coach. He is the one who have helped us a lot." For his part, C3n referred to the intervention of the job coach in specific situations:

Well, the fact of having a reference person I think is super important. [...] Whenever there is a problem like this, which repeats itself over time, we warn him and he comes and talks to her (the worker) and they end up solving it or they find the reason for this problem. 


\section{Key factors that act as an obstacle}

Lack of a period of adaptation of the worker to the working environment. This refers to the need for an adaptation period so the IDD worker can adapt mutually to his/her new job and colleagues.

Some participants mentioned this factor as an obstacle as, at first, difficulties appeared because the task did not fit the abilities of the person with IDD or communication difficulties because of their shyness, as $\mathrm{C} 1$ commented: "At first, she was like a ghost. Not now. When she passed by, she didn't even say 'hello'. Not now."

\section{Discussion}

Overall, task planning and scheduling, monitoring and follow-up, the quality of the relationship and communication, the attitude and capacity of the worker and how is the disability understood are identified as critical factors in the work of people with IDD that potentially could act as facilitators or as obstacles, depending on how they are managed. Besides, the corporate social responsibility and the role of the job coach are clearly shown as a facilitator, and the lack of a period of adaptation, as an obstacle.

In a recent paper, Wehman et al. (2014) stated that SE emerged as the gold standard for the employment outcomes of people with IDD. In addition, results of various studies clearly support the effectiveness of SE in promoting successful and sustained work in this population group (Beyer et al., 2010; Bond et al., 2001; Qian et al., 2018; Wehman et al., 2014).

The literature shows that in the past 20 years, numerous studies identified the results and the barriers to SE, especially in the USA, UK, Canada and Australia. In fact, these results refer to more structural aspects such as the evolution of the number of workers, competitive wages, daily worked hours, the number of hours of support, the continuity of the worker, the role of the job coach and the coworker mentor and the impact on the quality of life (Jordán de Urríes et al., 2006; Mank et al., 2003; Wehman and Bricout, 1999). However, there is a scarcity of studies that had reported qualitative data of what happens to the worker in the workplace. Complementarily, the European Union of Supported Employment (EUSE) (2005) proposed what it considers to be the SE quality standards organized in three sections: organization, process and outcomes. It also stated a series of principles and values that underpin the SE.

Research in Spain runs parallel to international research, although it is fair to point out that SE, after 30 years of the first initiative, basically only received the attention of Instituto Universitario de Integración en la Comunidad (INICO) researchers who developed multiple and notorious initiatives. INICO has focused on the results of SE, as well as its impact on the quality of life perceived by workers (Jordán de Urríes et al., 2006; Jordán de Urríes et al., 2012; Santamaría et al., 2012; Verdugo et al., 2006; Verdugo et al., 2009). Moreover, the studies carried out by INICO also aimed at describing, analyzing and disseminating the situation and advantages of SE (Jordán de Urríes and Verdugo, 2003; Jordán de Urríes et al., 2005).

Consequently, the results presented in this study provide new information about the reality of SE in Spain as, in addition to some structural results, they also include variables relating to the factors about management and organizational culture of workers with IDD in their workplace. Specifically, the current research allowed us to identify and go deeper into some key elements that, depending on how they behave in a given situation, may act as facilitators or as obstacles to the SE of people with IDD. On the one hand, our results partly coincide with those shown in the international literature and, on the other, confirm some components of the quality standards of European Union of Supported Employment (EUSE) (2005) that have just been mentioned. 
In addition, Jordán de Urríes et al. (2012) consider that, in general, the European Union of Supported Employment (EUSE) standards, that are organized around three key sections (organization, process and outcomes), should be redefined through research to better adjust them to the different variables that affect the SE. So, our results are aligned with the proposal of Jordán de Urríes et al. (2012) to the extent that they allow us to concrete some of the EUSE standards in measures that listening to the voice of the workers and of the coworkers mentors are revealed as crucial factors.

Bond et al. (2001) state that work organization, type of task and monitoring contribute to the success of SE. Our results confirm their findings, particularly regarding the need to find jobs according to the preferences and strengths of IDD workers, as well as to be able to count on adequate monitoring. In the same sense, Workforce Innovation Technical Assistance Center (WINTAC) (2018) pointed out that two of the key elements for the success of SE are job site training and follow-up through ongoing support. It is worth noting that this organization includes in its ongoing support the negotiation of changes in the task, which coincides with our results.

Another of our results highlights the importance of the quality of the relationship with the supervisor and colleagues for the success and maintenance of the job. This being a key component of success, unfortunately it does not seem to have been a sufficiently studied topic. As Qian et al. (2018) recognized, researchers have given less attention to more personal aspects such as job satisfaction or career advancement.

Our results coincide with those of Wehman and Bricout (1999), Mank et al. (2003) and Workforce Innovation Technical Assistance Center (WINTAC) (2018) in the critical importance for the success of SE of the presence and accompaniment of the job coach, of the involvement of the coworker mentor, which can facilitate social relations and integration and of the role of the supervisor who can make work routines more flexible. The job coach gives continuous support to the worker in collaboration with the coworker mentor, the supervisor and the other workers and helps to make decisions based on the preferences and support needs of the worker (Workforce Innovation Technical Assistance Center [WINTAC], 2018). Mank et al. (2003) stated that providing information and support to the coworker mentor, the supervisor and colleagues in the workplace, was associated with good SE results. Support inside and outside the workplace was also considered a quality standard by European Union of Supported Employment (EUSE) (2005).

We have noticed that the ability and other personal characteristics of the worker, including attitude, can facilitate or, failing that, limit the success of SE. In her literature review, Payne (2015) stated that the lack of job skills by the worker puts both access and maintenance of the job at risk. Our results coincide with those of Payne (2015) by showing that the capacity and attitude of the worker can be a cause of non-compliance with the obligations, so it is necessary to train the disabled worker as well as plan a period of adaptation, to which we will refer later.

The understanding of disability by the supervisor and colleagues also represents a key element for the success of SE. The available literature is conclusive in this regard. Ready, Willing and Able (RWA) (2015) identified as a key element, the confidence and understanding of disability by the supervisor and colleagues, and stated that many employers acknowledged having an evident lack of knowledge. Mank et al. (2003) stated that companies that provide knowledge and training on human diversity and disability to their workers achieved better results and the relationship with colleagues was better; European Union of Supported Employment (EUSE) (2005) included company involvement as a quality standard; also, Payne (2015) saw as a barrier erroneous beliefs and myths about IDD workers on the part of employers.

Finally, the available literature confirms the need to plan a period of adaptation that allows the acquisition of the necessary skills, the adjustment of tasks to the interests and support 
needs and a better knowledge of disability. Mank et al. (2003) pointed out that providing initial training and guidance to the worker was strongly associated with better results in SE, as well as providing information about support needs to both the supervisor and colleagues. Ready, Willing and Able (RWA) (2015) believed that the process of hiring and starting work was a key element for effective integration into the company.

However, although our research sheds light on the way forward, we must recognize, as did by Butterworth et al. (2017), that we have a long way to go to make SE the majority option for workers with IDD in Spain. The results, in terms of hiring, participation, social relation, compliance with obligations, salary, etc. remain improvable. On the other hand, workers with IDD are still mostly oriented toward protected employment, and there is neither funding from the government nor the necessary collaboration between the educational system, work and social welfare.

\section{Conclusions}

Our research allowed us to identify some key factors that act as facilitators or as obstacles to access and maintenance of a competitive job for adults with IDD in an ordinary company, complementing both the results obtained in this field in Spain and internationally.

We believe that these factors constitute a step forward as they represent a more qualitative look, based on the voice of the end users, at the experience of the worker in daily life in his or her workplace when faced with the obligations, tasks and relationships that every worker establishes with his or her supervisors and colleagues. These key factors, on the other hand, are mostly common to the success and satisfaction of all workers, so any measures that may eventually be taken concerning IDD workers can have a positive impact on the occupational health of the entire company.

It seems important to pay attention to the fact that the same factor may behave as a facilitator or as an obstacle depending on the management made by the different actors of both the most organizational variables and continuous support.

Finally, some practical implications in Spain can be derived from our findings that should necessarily be understood from a systemic perspective. The government should promote legislative and, above all, funding changes that prioritize the option in favor of SE instead of sheltered employment, as well as ensure the obligation of companies to hire people with disabilities and extend this obligation to companies with less than 50 workers without resorting to cheating. On the other hand, the agencies that today are giving support to workers with IDD to access and maintain a competitive employment, should be able to have the necessary funding to meet their obligations with dignity and quality. Finally, it is necessary to promote a better understanding and a different approach of employers and workers regarding people with IDD, moving from focusing on their limitations to value their capacities. This different approach, the confidence in the possibilities of these workers and the organizations of the tasks, with the necessary adjustments and with the help of the job coach, would undoubtedly be sufficient measures to allow greater access to workers with IDD at competitive employment.

In consequence, the results can be used so that company policies incorporate their corporate social responsibilities, open themselves to the possibility of hiring workers with IDD and the various actors make decisions toward the direction shown by the key factors mentioned.

\section{Limitations and future research directions}

The present study presents some limitations that we should consider. First, the number of participants in the research allowed us to better understand the factors involved in the process of entering the labor market of people with IDD, but possibly a large number of participants could provide a broader vision. However, the fact that in many of the interviews, 
the factors identified by the participants as key factors were repeated and led us to think that we reached the saturation point in the group of participants of Aura Foundation and that it would perhaps be interesting to extend the research in the future with participants from other institutions that provide SE.

In the same way, another limitation can be placed in the area of territorial representation, as our research focused on companies located in the city of Barcelona and its surroundings. Also, we cannot fail to mention the difficulty of trying to carry out an investigation with a large number of companies, as in general, they have little time to devote to activities that are beyond their scope and that often represent a distortion in their ordinary functioning.

Finally, we understand that our findings should necessarily be complemented by new research. On the one hand, other important voices must be heard to be able to complete the understanding of the SE process, such as the voice of the workers with IDD themselves, parents, policymakers and other stakeholders involved in SE; in this way, we could check to what extent these factors are confirmed or weather new ones should appear. On the other hand, it would also be interesting to further consider an investigation that includes other areas of Spain in the near future.

\section{References}

Abma, T.A. and Stake, R.E. (2014), "Science of the particular: an advocacy of naturalistic case study in health research", Qualitative Health Research, Vol. 24 No. 8, pp. 1150-1161, doi: 10.1177/ 1049732314543196.

Almalky, H.A. (2020), "Employment outcomes for individuals with intellectual and developmental disabilities: a literature review", Children and Youth Services Review, Vol. 109, pp. 1-41, doi: 10.1016/j. childyouth.2019.104656.

Alomar, E. (2004), "El treball dels joves amb retard mental en entorns normalitzats: anàlisi d'una realitat de treball amb suport", Phd thesis, Ramon Llull University, available at: www.tdx.cat/handle/10803/ 9238\#page $=8$ (accessed 5 March 2020)

Anguera, M.T., Arnau, J., Ato, M., Martínez, R., Pascual, J. and Vallejo, G. (1995), Métodos de Investigación en Psicología, Síntesis, Madrid.

Aura Foundation (2019), "Memòria 2018", available at: www.aurafundacio.org/wp-content/uploads/2019/ 07/Aura_Memoria_2018_cat_web.pdf (accessed 3 March 2020).

Beyer, S., Brown, T., Akandi, R. and Rapley, M. (2010), "A comparison of quality of life outcomes for people with intellectual disabilities in supported employment, day services and employment enterprises", Journal of Applied Research in Intellectual Disabilities, Vol. 23 No. 3, pp. 290-295, doi: 10.1111/j.14683148.2009.00534.x.

Bond, G.R., Becker, D.R., Drake, R.E., Rapp, C.A., Meisler, N., Lehman, A.F., Bell, M.D. and Blyler, C.R. (2001), "Implementing supported employment as an evidence-based practice", Psychiatric Services, Vol. 52 No. 3, pp. 313-322, doi: 10.1176/appi.ps.52.3.313

Braun, V. and Clarke, V. (2006), "Using thematic analysis in psychology", Qualitative Research in Psychology, Vol. 3 No. 2, pp. 77-101, doi: 10.1191/1478088706qp063oa.

Buntix, W.H.E. and Schalock, R.L. (2010), "Models of disability, quality of life, and individualized supports: implications for professional practice in intellectual disability", Journal of Policy and Practice in Intellectual Disabilities, Vol. 7 No. 4, pp. 283-294.

Butterworth, J., Christensen, J. and Flippo, K. (2017), "Partnerships in employment: building strong coalitions to facilitate systems change for youth and young adults", Journal of Vocational Rehabilitation, Vol. 47 No. 3, pp. 265-276, doi: 10.3233/JVR-170901.

Departament de Treball (2009), El Treball Amb Suport a Catalunya. Protocol Marc, Departament de Treball. Generalitat de Catalunya, Barcelona.

Down España (2016), "Empleo con apoyo. Modelo de intervención Down España", available at: www. sindromedown.net/wp-content/uploads/2016/03/Modelo-de-intervención-DOWN-ESPA-A-Empleo-conApoyo-Ed.2016.pdf (accessed 2 March 2020). 
European Union of Supported Employment (EUSE) (2005), Folletoinformativo y Modelo de Calidad, EUSE, Belfast.

Instituto Nacional de Estadística (2008), "Panorámica de la discapacidad en España", available at: www. ine.es/revistas/cifraine/1009.pdf (accessed 13 June 2019).

Jordán de Urríes, F.B. and Verdugo, M.A. (2003), El Empleo Con Apoyo en España. Análisis de Variables Que Determinan la Obtención y Mejora de Resultados en el Desarrollo de Servicios, 2nd ed., Real Patronato sobre Discapacidad, Madrid.

Jordán de Urríes, F.B. and Verdugo, M.A. (2012), "Open employment in Spain, why have we still not taken the decisive step", Journal of Vocational Rehabilitation, Vol. 37 No. 3, pp. 147-154, doi: 10.3233/JVR2012-0609.

Jordán de Urríes, B.J., Verdugo, M.A. and Jenaro, C. (2006), "Tipicidad, calidad de vida y mejora de los resultados en empleo con apoyo", in Verdugo, M.A. (Ed.), Como Mejorar la Calidad de Vida de Las Personas Con Discapacidad: instrumentos y Estrategias de Evaluación, Amarú, Salamanca, pp. 143-176.

Jordán de Urríes, F.B., Verdugo, M.A. and Vicent, C. (2005), Análisis de la Evolución Del Empleo Con Apoyo en España, 3th ed., Real Patronato sobre Discapacidad, Madrid.

Jordán de Urríes, F.B., Verdugo, M.A., Fernández, R. and Santamaría, M. (2012), "Estándares de calidad EUSE y resultados en empleo con apoyo. Prácticas basadas en la evidencia", paper presented at the VIII Jornadas Científicas Internacionales de Investigación sobre Personas con Discapacidad: Simposios, Comunicaciones y Posters. Cambio organizacional y apoyo a las graves afectaciones. Dos prioridades, 14-16 March, Salamanca, available at: https://inico.usal.es/cdjornadas2012/inico/docs/510.pdf (accessed 3 September 2018).

Kvale, S. (2011), Las Entrevistas en Investigación Cualitativa, Morata, Madrid.

Mank, D., Cioffi, A. and Yovanoff, P. (2003), "Supported employment outcomes across a decade: is there evidence of improvement in the quality of implementation?", Mental Retardation, Vol. 41 No. 3, pp. 188-197.

Nirje, B. (1980), "The normalization principle", in Flynn, R.J. and Nitsh, K.E. (Eds), Normalization, Social Integration, and Community Services, University Park Press, Baltimore, MD.

Observatorio Estatal de la Discapacidad (2017), "Realidad, situación, dimensión y tendencias del empleo con apoyo en España en el horizonte del año 2020", available at: www.empleoconapoyo.org/ aese/IMG/pdf/Informe_OED_ECA_v3.pdf (accessed 4 March 2020).

Pallisera, M., Fullana, J. and Vila, M. (2005), "La inserción laboral de personas con discapacidad. Desarrollo de tres investigaciones acerca de los factores favorecedores de los procesos de inserción", Revista de Investigación Educativa, Vol. 23 No. 2, pp. 295-313.

Payne, C.A. (2015), "Overcoming barriers to assist individuals with intellectual disabilities obtain employment outcomes", research paper, Southern Illinois University Carbondale, available at: http:// opensiuc.lib.siu.edu/gs_rp (accessed 15 September 2019).

Poland, B.D. (2002), "Transcription quality", in Gubrium, J.F. and Holstein, J.A. (Eds), Handbook of Interview Research: Context \& Method, Sage Publications, Thousand Oaks, pp. 629-650.

Qian, X., Papay, C., Chaxiong, P. and Johnson, D.R. (2018), "Literature review of employment outcomes for adults with intellectual and developmental disability", International Review of Research in Developmental Disabilities, Vol. 55, pp. 213-266, doi: 10.1016/bs.irrdd.2018.08.006.

Ready, Willing and Able (RWA) (2015), "Building an inclusive labour force. Key elements", available at: http://readywillingable.ca/key-elements/ (accessed 22 September 2019).

Revell, G., Inge, K. J., Mank, D. and Wehman, P. (Eds) (1999), "The impact of supported employment for people with significant disabilities: preliminary findings from the national supported employment consortium", avalaible at: https://vcurrtc.org/research/printview.cfm/111 (accessed 22 October 2019).

Riessman, C.K. (1993), Narrative Analysis, Sage Publications, Newbury Park, CA.

Santamaría, M., Verdugo, M.A., Orgaz, B., Gómez, L.E. and Jordán de Urríes, F.B. (2012), "Calidad de vida percibida por trabajadores con discapacidad intelectual en empleo ordinario", Siglo Cero, Vol. 43 No. 2, pp. 46-61.

Schalock, R.L., Bonham, G.S. and Verdugo, M.A. (2008), "The conceptualization and measurement of quality of life: implications for program planning and evaluation in the field of intellectual disabilities", Evaluation and Program Planning, Vol. 31 No. 2, pp. 181-190, doi: 10.1016/j.evalprogplan.2008.02.001. 
Thompson, J.R., Bradley, V.J., Buntinx, W.H.E., Schalock, R.L., Shogren, K.A., Snell, M.E. and Wehmeyer, M.L. (2009), "Conceptualizing supports and the support needs of people with intellectual disability", Intellectual and Developmental Disabilities, Vol. 47 No. 2, pp. 135-146, doi: 10.1352/19349556-47.2.135.

Verdugo, M.A., Jordán de Urríes, F.B. and Bellver, F. (1998), "Situación actual del empleo con apoyo en españa", Siglo Cero No 175, Vol. 29 No. 1, pp. 23-31.

Verdugo, M.A., Jordán de Urríes, F.B., Jenaro, C., Caballo, C. and Crespo, M. (2006), "Quality of life of workers with and intellectual disability in supported employment", Journal of Applied Research in Intellectual Disabilities, Vol. 19 No. 4, pp. 309-316.

Verdugo, M.A., Martín, R., Jordán de Urríes, F.B., Vicent, C. and Sánchez, M.C. (2009), "Impact on quality of life and self-determination of a national program for increasing supported employment in Europe", Journal of Vocational Rehabilitation, Vol. 31 No. 1, pp. 55-64.

Wehman, P. (2012), "Supported employment: what is it?", Journal of Vocational Rehabilitation, Vol. 37, pp. 139-142, doi: 10.3233/JVR-2012-0607.

Wehman, P. and Bricout, J. (1999), "Supported employment: critical issues and new directions", avalaible at: https://vcurrtc.org/research/printview.cfm/111 (accessed 22 October 2019).

Wehman, P., Chan, F., Ditchman, N. and Kang, H. (2014), "Effect of supported employment on vocational rehabilitation outcomes of Transition-Age youth with intellectual and developmental disabilities: a case control study", Intellectual and Developmental Disabilities, Vol. 52 No. 4, pp. 296-310, doi: 10.1352/19349556-52.4.296.

Wolfensberger, W. (1972), The Principle of Normalization in Human Services, National Institute on Mental Retardation, Toronto.

Workforce Innovation Technical Assistance Center (WINTAC) (2018), "Core features of quality supported employment services", available at: http://wintac-s3.s3-us-west-2.amazonaws.com/topic-areas/ ta03_IntCompetEmpl/SE-QualityFeatures-FinalVersion19-0130-v8.pdf (accessed 19 September 2019).

Yin, R.K. (2018), Case Study Research and Applications: design and methods, 6th ed., Sage publications, Thousand Oaks, CA.

\section{Further reading}

Luckasson, R., Coulter, D.L., Polloway, E.A., Reiss, S., Schalock, R.L., Snell, M.E., Spitalnik, D.M. and Stark, J.A. (1992), Mental Retardation. Definition, Classification and Systems of Supports, American Association on Mental Retardation, Washington, DC.

\section{Corresponding author}

Miquel Àngel Pellicena can be contacted at: miquelangelps@blanquerna.url.edu

For instructions on how to order reprints of this article, please visit our website: www.emeraldgrouppublishing.com/licensing/reprints.htm

Or contact us for further details: permissions@emeraldinsight.com 